\title{
Fruit and Nut Genebanks in the U.S. National Plant Germplasm System
}

\author{
Joseph Postman ${ }^{1}$ and Kim Hummer \\ U.S. Department of Agriculture (USDA)-Agricultural Research Service (ARS), \\ National Clonal Germplasm Repository (NCGR), Corvallis, OR 97333-2521
}

Ed Stover

USDA-ARS, NCGR, Davis, CA 95616

Robert Krueger

USDA-ARS, NCGR, Riverside, CA 92507

Phillip Forsline

USDA-ARS, Plant Genetic Resource Unit, Geneva, NY 14456

L.J. Grauke

USDA-ARS, NCGR, Somerville, TX 77879

Francis Zee

U.S. Department of Agriculture-Agricultural Research Service, National Clonal Germplasm Repository, Hilo, HI 96720

Tomas Ayala-Silva

USDA-ARS, NCGR, Miami, FL 33158

\section{Brian Irish}

\section{USDA-ARS, Tropical Agriculture Research Station, Mayaguez, PR 00680}

Additional index words. genetic resources, clonal repository, genetics, conservation, disease resistance, environmental adaptation

\begin{abstract}
The year 2005 marked the 25th anniversary of the establishment of the U.S. Department of Agriculture (USDA) National Plant Germplasm System (NPGS), repositories devoted to clonally propagated, horticultural fruit and nut crops. During this quarter century, facilities in Hilo, Hawaii; Mayaguez, PR.; Miami, Fla.; and Riverside, Calif. were developed to preserve collections of tropical and subtropical fruit and nut crops; facilities in Brownwood, Texas; Corvallis, Ore.; Davis, Calif. and Geneva, N.Y. preserve the temperate crops. Each of these facilities now has internationally recognized, globally diverse collections of genetic resources for their assigned genera. Germplasm of unique genotypes are maintained as growing plants, evaluated for phenotypic and genotypic traits, documented in a national public germplasm database, and freely distributed as clonal propaggules to researchers and other germplasm users around the world. Seed collections represent wild populations for some crop relatives. These 8 genebanks maintain 30,000 accessions representing 1600 species of fruit and nut crops and their wild relatives. The genebanks distribute more than 15,000 accessions annually to international researchers. Although originally conceived as working collections for crop improvement, NPGS genebanks have also become invaluable in providing the raw materials for basic plant genetic research, reservoirs for rare or endangered species or vulnerable landraces, archives of historic cultivars, and field classrooms for educating the public. These collections preserve botanical treasures as well as the American horticultural heritage for now and for future generations.
\end{abstract}

History of U.S. National Fruit and Nut Repositories

Before 1980, fruit and nut germplasm collections in the United States were largely

Received for publication 3 Mar. 2006. Accepted for publication 7 Apr. 2006.

We thank Mel Westwood for his oral history and for reviewing the manuscript. We thank the technical staff at each of the NPGS Clonal Repositories for their dedicated stewardship of these invaluable collections.

${ }^{1}$ To whom correspondence should be addressed; e-mail jpostman@ars-grin.gov.
Over the next several years, this unit was followed by the construction of 7 additional repositories at specifically chosen sites throughout the country (CAST, 1985; Westwood, 1986, 1989).

The USDA Agricultural Research Service (ARS) has operated 4 regional PI stations in Ames, Iowa (established 1947), Pullman, Wash. (established 1947), Geneva, N.Y. (established 1948), and Griffin, Ga. (established 1949) to receive, preserve, and distribute seed of vegetable and agronomic crops (Fig. 1). Several additional repositories were later added for special crops such as cotton, potatoes, and soybeans. In 1958, the National Seed Storage Laboratory (now the National Center for Genetic Resource Preservation) opened in Fort Collins, Colo., to ensure the long-term "base, backup" preservation of seeds from each of the "working" or actively distributing collections (White et al., 1989). This network of federal genebanks came to be known as the National Plant Germplasm System (NPGS). Clonal repositories were added to the NPGS as a result of the efforts of ARS pear breeder Howard Brooks, who chaired a visionary group of researchers who forwarded this cause. Dr. Brooks formed an ad hoc clonal committee after a workshop at the 1974 meeting of the American Society for Horticultural Science (White et al., 1989). Brooks asked each committee member in 1977 to develop a plan for a national repository for crops important in their region of the country. He requested that the plans specifically itemize the necessary space for land, greenhouses, laboratories, and offices needed to safeguard the germplasm of the regional crops (Brooks and Barton, 1977). During the next winter, armed with these plans, Brooks appeared before the U.S. Congressional Committee on Agriculture in Washington, DC, to request federal funding to establish a system of National Clonal Repositories. The congressmen approved the concept and asked Brooks to develop a more specific plan to be presented to them in the next year. They were very impressed when he opened his briefcase and pulled out the detailed plans that his committee had already assembled for 12 repository sites (M.N. Westwood, Nov. 2005, personal communication). During that very same session of Congress, a \$2 million federal appropriation was approved to begin building a system of National Clonal Germplasm Repositories. This request was to be a joint effort matched through mutual agreement with State Agricultural Experiment Stations at Land Grant Universities. The Corvallis, Ore. Repository was selected as the first to be constructed because of the large collections of pears, hazelnuts, and small fruits already present at that site. The very active involvement of Dr. Wilson Foote, Associate Director of the Oregon State University Agricultural Experiment Station, pomology Professor, Dr. Melvin Westwood, and hazelnut breeder, Dr. Maxine Thompson, encouraged this choice. Dr. Westwood was later appointed as National Technical Advisor for Clonal 


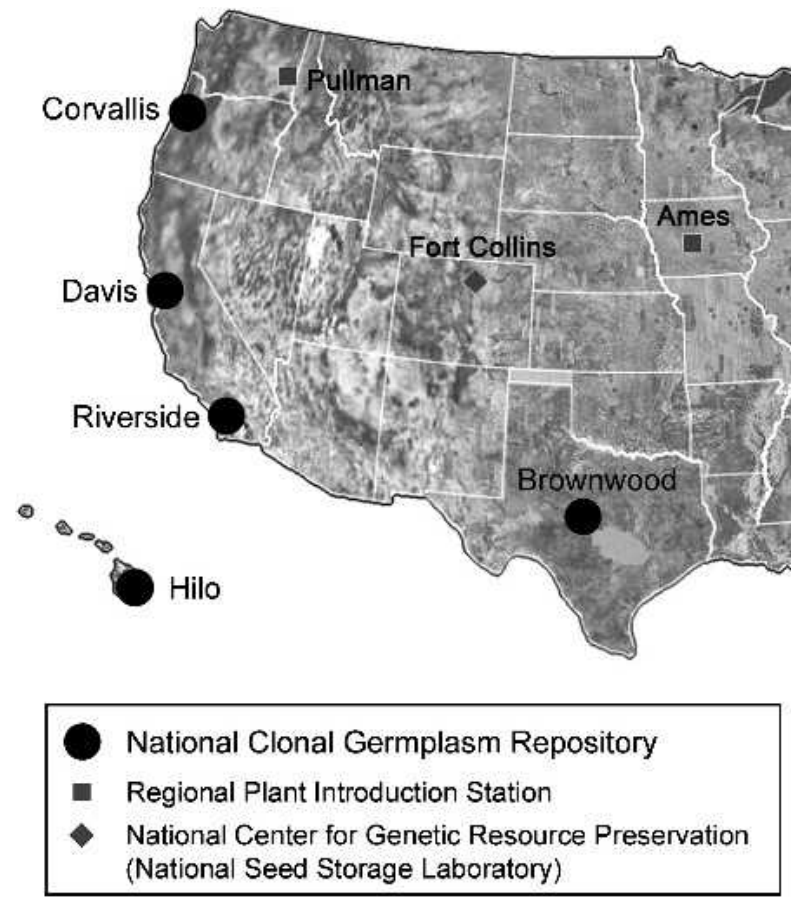

Fig. 1. Locations of USDA National Plant Germplasm System clonal genebanks for fruit and nut crops.

Germplasm during the construction of the clonal repositories and developed an operations manual to guide new staff in establishing their facilities (Westwood, 1986). Funding was ultimately approved for 8 of the 12 originally planned clonal repositories (Fig. 1). Two Citrus repositories, one in Orlando, Florida, and one in Riverside, California, were originally established as a result of quarantine restrictions between the 2 states but were later consolidated at Riverside. In 1987, the National Arboretum in Washington, DC, was designated as a clonal repository for woody landscape crops.

\section{NPGS ‘Clonal' Repositories}

The mission of NPGS genebanks includes the acquisition, documentation, preservation, evaluation, enhancement, and distribution of plant genetic resources. This conservation activity improves the quality and production of economic crops important to U.S. and world agriculture (NPGS, 2005a). The U.S. clonal genebanks house wild relatives as well as improved genotypes for their assigned crops and currently maintain 30,000 accessions representing 1600 species (Table 1). For some temperate crops, seed collections are used to represent wild species populations in addition to the genotypes that must be preserved clonally. Many nut crops and tropical or subtropical species have recalcitrant seeds that do not retain viability when stored so that clonal living plant conservation is required. The original plan for fruit and nut gene banks suggested maintenance and preservation as primary objectives followed by research and evaluation (Brooks and Barton, 1977; Westwood, 1989). Preservation remains the primary focus of the NPGS fruit and nut repositories, which are described subsequently in the order that they became established. Contact information and crop responsibilities for each site are provided (Table 2), and number of accessions and collection locations by genus are itemized (Table 1).

\section{Corvallis, Ore., established 1980}

NCGR-Corvallis is operated in collaboration with Oregon State University and is located on the grounds of their Horticultural Research Farm at $44.55^{\circ} \mathrm{N}$ latitude. NCGRCorvallis maintains germplasm collections of more than 26 genera, including several agronomic and specialty crops. Actinidia, Corylus, Cydonia, Fragaria, Pyrus, Ribes, Rubus, and Vaccinium are the main assigned fruit and nut genera (Table 2). The Repository maintains more than 8300 clones and 3300 seedlots. The largest clonal collections are Pyrus with 1900 and Fragaria with 1300 accessions. Because Rubus and Vaccinium are highly diverse, each having between 600 and 800 species worldwide, much variability for these genera is represented with seedlots. Currently, 970 Rubus and 570 Vaccinium seedlots are maintained in addition to a greater number of clones (Table 1).

Primary clonal collections of Fragaria, Rubus, and Vaccinium are maintained as potted plants in screenhouses for protection from virus vectors. Primary clonal collections for Actinidia, Corylus, Cydonia, Pyrus, and Ribes are maintained in field collections on 26 ha of land available to the Repository east of Corvallis. Much of the Ribes and Vaccinium collections are duplicated in both screenhouse and field. In vitro culture of growing shoots provides backup for approximately $10 \%$ of the collection with priority given to core accessions, frequently requested accessions, and accessions that may
Table 1. Fruit and nut collections at the 8 USDA NPGS Clonal Repositories (NPGS, 2006).

\begin{tabular}{|c|c|c|c|}
\hline Genus & Site $^{z}$ & Accessions $^{\mathrm{y}}$ & Species \\
\hline Actinidia & COR & 198 & 27 \\
\hline Actinidia & DAV & 68 & 14 \\
\hline Aegle & RIV & 1 & 1 \\
\hline Aeglopsis & RIV & 1 & 1 \\
\hline Afraegle & RIV & 1 & 1 \\
\hline Aleurites & MAY & 2 & 1 \\
\hline Amelanchier & COR & 226 & 15 \\
\hline Ampelopsis & DAV & 21 & 6 \\
\hline Ampelopsis & GEN & 5 & 3 \\
\hline Anacardium & MAY & 1 & 1 \\
\hline Ananas & $\mathrm{HI}$ & 160 & 10 \\
\hline Annamocarya & BRW & 11 & 1 \\
\hline Annona & MAY & 16 & 6 \\
\hline Annona & MIA & 70 & 10 \\
\hline Antidesma & MAY & 3 & 1 \\
\hline Archontophoenix & MIA & 3 & 3 \\
\hline Aronia & COR & 7 & 1 \\
\hline Artocarpus & $\mathrm{HI}$ & 39 & 5 \\
\hline Artocarpus & MAY & 10 & 7 \\
\hline Artocarpus & MIA & 4 & 1 \\
\hline Asimina & COR & 70 & 7 \\
\hline Atalantia & RIV & 6 & 4 \\
\hline Averrhoa & $\mathrm{HI}$ & 25 & 1 \\
\hline Averrhoa & MAY & 19 & 1 \\
\hline Averrhoa & MIA & 38 & 1 \\
\hline Bactris & $\mathrm{HI}$ & 15 & 1 \\
\hline Bactris & MAY & 3 & 1 \\
\hline Bactris & MIA & 16 & 3 \\
\hline Balsamocitrus & RIV & 1 & 1 \\
\hline Bertholetia & MAY & 1 & 1 \\
\hline Bismarckia & MIA & 1 & 1 \\
\hline Bixa & MAY & 1 & 1 \\
\hline Blighia & MIA & 1 & 1 \\
\hline Brosimum & MIA & 1 & 1 \\
\hline Butea & MIA & 1 & 1 \\
\hline Butia & MIA & 11 & 1 \\
\hline Camellia & $\mathrm{HI}$ & 18 & 1 \\
\hline Canarium & $\mathrm{HI}$ & 16 & 8 \\
\hline Carica & $\mathrm{HI}$ & 143 & 1 \\
\hline Carissa & MIA & 1 & 1 \\
\hline Carya & BRW & 1340 & 23 \\
\hline Caryota & MIA & 3 & 1 \\
\hline Casimiroa & MAY & 2 & 1 \\
\hline Casimiroa & MIA & 3 & 1 \\
\hline Cavendishia & COR & 7 & 4 \\
\hline Ceanothus & COR & 37 & 9 \\
\hline Chaenomeles & COR & 13 & 3 \\
\hline Chrysobalanus & MAY & 2 & 1 \\
\hline Chrysophyllum & MAY & 2 & 1 \\
\hline Cinnamomum & MAY & 5 & 3 \\
\hline Cinnamoтum & MIA & 2 & 1 \\
\hline Citremocitrus & RIV & 1 & 1 \\
\hline Citrofortunella & RIV & 8 & 1 \\
\hline Citromicrocitrus & RIV & 1 & 1 \\
\hline Citroncirus & RIV & 43 & 1 \\
\hline Citropsis & RIV & 4 & 4 \\
\hline Citrus & MAY & 4 & 1 \\
\hline Citrus & RIV & 896 & 86 \\
\hline Clausena & RIV & 6 & 4 \\
\hline Clymenia & RIV & 1 & 1 \\
\hline Coccothrinax & MIA & 16 & 7 \\
\hline $\operatorname{Cocos}$ & MAY & 1 & 1 \\
\hline Cocos & MIA & 20 & 1 \\
\hline Coffea & MAY & 1 & 1 \\
\hline Cola & MAY & 4 & 1 \\
\hline Coleara & RIV & 1 & 1 \\
\hline Copernicia & MIA & 9 & 9 \\
\hline Cornus & COR & 9 & 1 \\
\hline Corylus & COR & 795 & 22 \\
\hline Corypha & MIA & 2 & 1 \\
\hline Crataegomespilus & $\mathrm{COR}$ & 3 & 1 \\
\hline Crataegus & COR & 18 & 8 \\
\hline Crataemespilus & COR & 1 & 1 \\
\hline Cryosophila & MIA & 4 & 1 \\
\hline
\end{tabular}

(Continued) 
Table 1. (Continued) Fruit and nut collections at the 8 USDA NPGS Clonal Repositories (NPGS, 2006)

\begin{tabular}{|c|c|c|c|c|c|c|c|}
\hline & \multirow{2}{*}{$\begin{array}{l}\text { Manilkara } \\
\text { Manilkara }\end{array}$} & \multirow{2}{*}{$\begin{array}{l}\text { MAY } \\
\text { MIA }\end{array}$} & \multirow{2}{*}{$\begin{array}{l}26 \\
12\end{array}$} & \\
\hline Genus & Site $^{z}$ & Accessions $^{y}$ & Species & & & & \\
\hline Cudrania & DAV & 1 & 1 & Mentha & COR & 533 & 40 \\
\hline Cydonia & COR & 114 & 1 & Merrillia & RIV & 1 & 1 \\
\hline Dictyosperma & MIA & 5 & 1 & Mespilus & COR & 48 & 3 \\
\hline Dimocarpus & $\mathrm{HI}$ & 19 & 1 & Microcitronella & RIV & 1 & 1 \\
\hline Dimocarpus & MAY & 2 & 1 & Microcitrus & RIV & 19 & 6 \\
\hline Dimocarpus & MIA & 4 & 1 & Micromelum & RIV & 2 & 1 \\
\hline Diospyros & DAV & 103 & 4 & Monstera & MAY & 1 & 1 \\
\hline Diospyros & MAY & 3 & 1 & Morus & DAV & 58 & 8 \\
\hline Diospyros & MIA & 9 & 5 & Murraya & RIV & 3 & 1 \\
\hline Dovyalis & MAY & 2 & 1 & Musa & MAY & 112 & 4 \\
\hline Duchesnea & COR & 3 & 1 & Musa & MIA & 73 & 3 \\
\hline Durio & $\mathrm{HI}$ & 3 & 3 & Naringi & RIV & 1 & 1 \\
\hline Durio & MAY & 1 & 1 & Nephelium & $\mathrm{HI}$ & 38 & 6 \\
\hline Dypsis & MIA & 11 & 6 & Nephelium & MIA & 1 & 1 \\
\hline Dyschoriste & MIA & 1 & 1 & Olea & DAV & 139 & 4 \\
\hline Ehretia & MIA & 2 & 1 & Oreomunnea & DAV & 1 & 1 \\
\hline Elaeis & MIA & 16 & 1 & Oxanthera & RIV & 1 & 1 \\
\hline Elaeocarpus & MIA & 2 & 1 & Pachira & MAY & 1 & 1 \\
\hline Empetrum & $\mathrm{COR}$ & 8 & 1 & Pamburus & RIV & 2 & 1 \\
\hline Eremocitrus & RIV & 1 & 1 & Paramignya & RIV & 2 & 1 \\
\hline Eriobotrya & DAV & 29 & 1 & Parmentiera & MAY & 2 & 1 \\
\hline Esenbeckia & RIV & 1 & 1 & Parthenocissus & DAV & 2 & 1 \\
\hline Eugenia & $\mathrm{HI}$ & 1 & 1 & Parthenocissus & GEN & 1 & 1 \\
\hline Eugenia & MAY & 2 & 1 & Passiflora & $\mathrm{HI}$ & 34 & 9 \\
\hline Eugenia & MIA & 2 & 1 & Peraphyllum & COR & 8 & 1 \\
\hline Euterpe & MIA & 8 & 3 & Persea & MIA & 252 & 3 \\
\hline Feroniella & RIV & 1 & 1 & Phoenix & MIA & 27 & 7 \\
\hline Ficus & DAV & 196 & 4 & Phoenix & RIV & 69 & 1 \\
\hline Ficus & MIA & 87 & 47 & Pimenta & MIA & 1 & 1 \\
\hline Flacourtia & MAY & 3 & 3 & Piper & MAY & 2 & 1 \\
\hline Flacourtia & MIA & 1 & 1 & Pistacia & DAV & 218 & 12 \\
\hline Fortucitrocirus & RIV & 3 & 1 & Pleiospermium & RIV & 3 & 1 \\
\hline Fortunella & MAY & 1 & 1 & Poncirus & RIV & 54 & 1 \\
\hline Fortunella & RIV & 11 & 7 & Potentilla & COR & 3 & 1 \\
\hline Fragaria & COR & 1734 & 37 & Pouteria & MAY & 27 & 1 \\
\hline Fragotentilla & COR & 3 & 1 & Pouteria & MIA & 40 & 5 \\
\hline Garcinia & MAY & 16 & 12 & Pritchardia & MIA & 1 & 1 \\
\hline Garcinia & MIA & 22 & 9 & Prunus & DAV & 1330 & 87 \\
\hline Gastrococos & MIA & 1 & 1 & Prunus & GEN & 106 & 14 \\
\hline Gaultheria & COR & 42 & 17 & Pseudananas & $\mathrm{HI}$ & 1 & 1 \\
\hline Gaylussacia & COR & 15 & 5 & Pseudocydonia & COR & 1 & 1 \\
\hline Genipa & MIA & 1 & 1 & Pseudophoenix & MIA & 3 & 1 \\
\hline Glycosmis & RIV & 4 & 4 & Psidium & $\mathrm{HI}$ & 44 & 5 \\
\hline Hevea & MIA & 44 & 1 & Psidium & MAY & 4 & 3 \\
\hline Hicksbeachia & $\mathrm{HI}$ & 2 & 1 & Pterocarya & DAV & 11 & 6 \\
\hline Hippophae & COR & 2 & 1 & Punica & DAV & 149 & 1 \\
\hline Hyophorbe & MIA & 3 & 1 & Pyracomeles & COR & 1 & 1 \\
\hline Hyphaene & MIA & 1 & 1 & Pyronia & COR & 7 & 1 \\
\hline Inga & MAY & 1 & 1 & Pyrus & COR & 2180 & 37 \\
\hline Inga & MIA & 2 & 1 & Ribes & COR & 1324 & 109 \\
\hline Jacaratia & $\mathrm{HI}$ & 1 & 1 & Rollinia & MAY & 1 & 1 \\
\hline Juglans & COR & 70 & 3 & Roystonea & MIA & 7 & 4 \\
\hline Juglans & DAV & 425 & 23 & Rubus & COR & 2078 & 192 \\
\hline Lansium & MAY & 1 & 1 & Rubus & MAY & 2 & 1 \\
\hline Lecythis & MAY & 2 & 1 & Ruscus & COR & 1 & 1 \\
\hline Leucaena & $\mathrm{HI}$ & 7 & 1 & Ruta & RIV & 1 & 1 \\
\hline Licania & MAY & 2 & 1 & Sabal & MIA & 23 & 5 \\
\hline Limonia & RIV & 1 & 1 & Saccharum & MIA & 2421 & 18 \\
\hline Litchi & HI & 63 & 1 & Salacca & MAY & 1 & 1 \\
\hline Litchi & MAY & 2 & 1 & Sambucus & COR & 183 & 21 \\
\hline Litchi & MIA & 18 & 1 & Sandoricum & MAY & 1 & 1 \\
\hline Livistona & MIA & 23 & 10 & Sapindus & MAY & 1 & 1 \\
\hline Lonicera & COR & 53 & 7 & Sauropus & $\mathrm{HI}$ & 1 & 1 \\
\hline Macadamia & $\mathrm{HI}$ & 26 & 5 & Schisandra & COR & 7 & 1 \\
\hline Macadamia & MAY & 1 & 1 & Severinia & RIV & 11 & 1 \\
\hline Macadamia & MIA & 1 & 1 & Sibbaldia & COR & 1 & 1 \\
\hline Madhuca & MIA & 1 & 1 & Sorbaronia & COR & 5 & 4 \\
\hline Malpighia & $\mathrm{HI}$ & 7 & 1 & Sorbocotoneaster & COR & 1 & 1 \\
\hline Malpighia & MIA & 14 & 3 & Sorbocrataegus & $\mathrm{COR}$ & 1 & 1 \\
\hline Malus & GEN & 3994 & 55 & Sorbopyrus & COR & 9 & 1 \\
\hline Mammea & MAY & 1 & 1 & Sorbus & $\mathrm{COR}$ & 282 & 60 \\
\hline Mangifera & MAY & 9 & 1 & Spondias & MIA & 3 & 1 \\
\hline Mangifera & MIA & 166 & 1 & Swinglea & RIV & 1 & 1 \\
\hline
\end{tabular}

Table 1. Continued.

\begin{tabular}{|c|c|c|c|}
\hline Genus & Site $^{z}$ & Accessions $^{\mathrm{y}}$ & Species \\
\hline Syzygium & $\mathrm{HI}$ & 3 & 1 \\
\hline Syzygium & MAY & 3 & 1 \\
\hline Syzygium & MIA & 5 & 3 \\
\hline Tamarindus & MAY & 1 & 1 \\
\hline Tamarindus & MIA & 35 & 1 \\
\hline Terminalia & MAY & 6 & 4 \\
\hline Theobroma & MAY & 156 & 1 \\
\hline Theobroma & MIA & 72 & 1 \\
\hline Thrinax & MIA & 17 & 3 \\
\hline Triphasia & RIV & 1 & 1 \\
\hline Vaccinium & COR & 1579 & 68 \\
\hline Vanilla & MAY & 1 & 1 \\
\hline Vasconcellea & HI & 24 & 9 \\
\hline Vitis & DAV & 2913 & 49 \\
\hline Vitis & GEN & 1203 & 26 \\
\hline Washingtonia & MIA & 1 & 1 \\
\hline Wenzelia & RIV & 1 & 1 \\
\hline Zingiber & MAY & 1 & 1 \\
\hline Ziziphus & MIA & 4 & 1 \\
\hline Site $^{z}$ & & Accessions $^{\mathrm{y}}$ & Specie \\
\hline Total for BRW & & 1351 & 24 \\
\hline Total for COR & & 11,682 & 722 \\
\hline Total for DAV & & 5664 & 223 \\
\hline Total for GEN & & 5309 & 99 \\
\hline Total for HI & & 690 & 77 \\
\hline Total for MAY & & 475 & 104 \\
\hline Total for MIA & & 3649 & 224 \\
\hline Total for RIV & & 1168 & 151 \\
\hline Grand Total & & 29,988 & 1624 \\
\hline
\end{tabular}

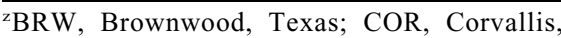
Oregon; DAV, Davis, California; GEN, Geneva, New York; HI, Hilo, Hawaii; MAY, Mayaguez, Pureto Rico; MIA, Miami, Florida; RIV, Riverside, California.

${ }^{y}$ Approximately 2700 Corvallis accessions are seedlots; approximately 1640 Geneva accessions are seedlots.

be at risk in the field resulting from lack of cold hardiness. Nonhardy genotypes and species originating in subtropical or tropical locations are also maintained year-round in a greenhouse. Seed collections are stored at $-20{ }^{\circ} \mathrm{C}$.

Research at Corvallis supported by base funding focuses on improving germplasm storage and maintenance, including in vitro culture and cryopreservation and development of molecular fingerprints (Bassil et al., 2005; Gupta and Reed, 2006; Lewers et al., 2005; Mehlenbacher et al., 2005; Reed, 2001; Reed et al., 2006). Other important research activities include virus and disease testing, identity verification, phenotype evaluation, propagation techniques, and strategies for seed regeneration.

\section{Davis, Calif., established 1981}

NCGR-Davis is operated in coordination with the University of California and is located at $38.54^{\circ} \mathrm{N}$ latitude. Fruit and nut crop genera which are represented by more than 100 clonal accessions include Actinidia, Diospyros, Ficus, Juglans, Olea, Pistacia, Prunus, Punica, and Vitis (Table 1). The Davis Repository currently holds over 5400 accessions representing approximately 15 genera and 175 species of fruit and nut crops. The two genera Vitis and Prunus account for approximately $75 \%$ of the collection with 2800 and 1300 accessions, respectively. 
Table 2. Curators, latitudes, contact information, and crop responsibilities for the fruit and nut repositories in the USDA National Plant Germplasm System.

\begin{tabular}{|c|c|c|}
\hline Site, latitude, curator & Contact info & Crop responsibilities \\
\hline Brownwood, Texas & USDA-ARS-NCGR & Carya (pecan, hickory) \\
\hline $31.71^{\circ} \mathrm{N}$ & 10200 FM 50 & \\
\hline L. J. Grauke & Somerville, TX 77879 & \\
\hline & phone (979) 272-1402 & \\
\hline & fax (979) 272-1401 & \\
\hline & e-mail: brwlg@ars-grin.gov & \\
\hline
\end{tabular}

Corvallis, Oregon

$44.55^{\circ} \mathrm{N}$

Kim Hummer, berries and specialty crops

Joseph Postman, pome fruits

Davis, California

$38.55^{\circ} \mathrm{N}$

Ed Stover

Geneva, New York

$42.88^{\circ} \mathrm{N}$

Phil Forsline

Hilo, Hawaii

$19.57^{\circ} \mathrm{N}$

Francis Zee

Miami, Florida

$25.64^{\circ} \mathrm{N}$

Tomas Ayala-Silva and Raymond Schnell, fruits, nuts

Alan Meerow, ornamentals

Mayaguez, Puerto Rico

$18.20^{\circ} \mathrm{N}$

Brian Irish and Ricardo Goenaga

Riverside, California

$33.96^{\circ} \mathrm{N}$

Robert Krueger
USDA-ARS-NCGR

33447 Peoria Road

Corvallis, OR 97333-2521

phone (541) 738-4200

fax (541) 738-4205

e-mail: cor@ars-grin.gov

USDA-ARS-NCGR

One Shield Ave, UCD

Davis, CA 95616-8607

phone (530) 752-7009

fax (530) 752-9659

e-mail: dav@ars-grin.gov

Plant Genetic Resource Unit Cornell University Exp. Station

$630 \mathrm{~W}$. North Street

Geneva, NY 14456-0462

phone (315) 787-2390

fax (315) 787-2339

e-mail: Philip.Forsline@ars.usda.gov

USDA-ARS-NCGR

PO Box 4487

928 Stainback Hwy.

Hilo, HI 96720

phone (808) 959-5833

fax (808) 959-3539

e-mail: fzee@pbarc.ars.usda.gov

USDA-ARS-NCGR

13601 Old Cutler Rd.

Miami, FL 33158

phone (305) 254-3635

fax (305) 969-6410

e-mail: mia@ars.grin.gov

USDA-ARS-TARS

2200 Pedro Albizu Campos

Ave. Suite 201

Mayaguez, PR 00680

phone (787) 831-3435

fax (787) 831-3386

e-mail: may@ars-grin.gov

USDA-ARS-NCGR

1060 Martin Luther King, Jr.

Blvd. Riverside, CA 92507-5437

phone (951) 827-4399

fax (951) 827-4398

e-mail: rivrk@ars-grin.gov
Actinidia (hardy kiwifruit) Amelanchier (service berry), Asimina (paw paw), Corylus (hazelnut), Cydonia (quince), Fragaria (strawberry), Humulus (hop), Juglans cinerea (butternut) Mentha (mint), Mespilus (medlar), Pyrus (pear), Ribes (currant, gooseberry) Rubus (blackberry, raspberry), Sorbus (mountain ash), Vaccinium (blueberry, cranberry)

Actinidia (kiwifruit), Diospyros (persimmon), Eriobotrya (loquat), Ficus (fig), Juglans (walnut), Morus (mulberry), Olea (olive), Pistacia (pistachio), Prunus (stone fruit, almond), Punica (pomegranate), Vitis (grape)

Malus (apple), Prunus cerasus (tart cherries), Vitis (hardy grape)

Ananas (pineapple), Artocarpus (breadfruit) Averrhoa (star fruit), Bactris (peach palm), Carica (papaya), Canarium (pilinut), Dimocarpus (longan), Litchi (lychee), Macadamia (macadamia), Malpighia (acerola), Nephelium (rambutan, pulasan), Passiflora (passion fruit), Psidium (guava)

Annona (cherimoya), Cocos nucifera (coconut), Dimocarpus (longan), Diospyros digyna (black sapote), Ficus (fig), Litchi (lychee), Mangifera (mango), Manilkara zapota (sapodilla), Musa spp. (banana), Persea (avocado), Pouteria sapota (mamey sapote), Saccarum (sugarcane) Theobroma cacao (cocoa), Zizyphus (jujube), subtropical and tropical ornamentals, Tripsacum and related grasses.

Annona (cherimoya), Garcinia, Manilkara zapota (níspero), Musa spp. (plantain, banana), Pouteria sapota (mamey sapote), Theobroma cacao (cocoa), temperate/tropical bamboo, other tropical ornamentals.

Citrus and Citrus relatives, Phoenix (date)
All collections are maintained with 2 trees or vines per accession on a 30-ha field site in Winters, Calif. Collections of Vitis and Pru$n u s$ are also maintained as potted plants in screenhouses for protection from disease vectors. Nonhardy genotypes and species originating in subtropical or tropical locations are maintained year-round in a greenhouse.

Research at Davis supported by base funding focuses primarily on use of molecular markers to fingerprint accessions, deter- mine the distribution of genetic variability within and between taxa, and to assist in collection management (Aradhya et al., 2003, 2004, 2005). Characterization of accession phenotypes, to assist clients in selecting material for their research programs, is also an important and ongoing research activity.

\section{Mayaguez, P.R., established 1984}

The Repository at Mayaguez is one of 4 NPGS genebanks devoted to the preservation of tropical and subtropical crops (Ayala-Silva et al., 2004). The Tropical Agriculture Research Station (TARS) at Mayaguez is located at $18.20^{\circ} \mathrm{N}$ latitude and dates back to 1908 . With the establishment of NPGS Clonal Repositories, TARS was designated as a site for the preservation of a number of tropical fruit and nut crops (Table 2). NPGS clonal germplasm activities in Mayaguez were initially administered by the curator in Miami, but this site now has its own curator and is no 
longer considered a substation of the Miami Repository. The Mayaguez genebank maintains more than 900 accessions of tropical fruit, nut, and ornamental landscape accessions representing 256 genera and over 400 species. The 450 clonal fruit and nut accessions maintained in field plots and greenhouses include primary collections of Manilkara (sapodilla), Musa, Pouteria (mamey or mammee sapote), Theobroma, several species of Annona and Garcinia, as well as temperate and tropical bamboos (Table 1). Some accessions are duplicated as backups for the Miami, Hilo, or Riverside Repositories. Research goals are directed toward maintenance of clonal germplasm collections and evaluation of accessions for phenotypic and genotypic descriptors. Genotypic characterization is focused on molecular approaches to determine genetic diversity baselines and clonal fingerprints. Development of in vitro tissue culture propagation for some collections will improve efficiency of propagation, ease of distribution, and lower the risk of pathogen dissemination.

\section{Miami, Fla., established 1984}

The Miami Repository is located at $25.64^{\circ}$ $\mathrm{N}$ latitude at the Subtropical Horticultural Research Station (SHRS). Approximately 5000 clonal accessions are maintained at SHRS in greenhouses, lathhouses, and field plots, representing sugar cane, Tripsacum, and subtropical woody ornamentals in addition to fruit and nut crops. Approximately 81 ha are available for research and germplasm preservation (Ayala-Silva et al., 2004). Important fruit and nut crops preserved at Miami include cacao, fig, lychee, mango, and other tropical and subtropical fruit species (Table 2). Accessions are maintained in field plantings, but certain new plants must be quarantined and tested for pathogens before moving to the field. Backup core collections have been established in Mayaguez or Hilo. Research at Miami is focused on improved horticultural practices to ensure the longevity of collections and on the genetic basis of important horticultural traits such as disease resistance. Molecular markers have been developed for genetic diversity analysis and for the production of molecular genetic linkage maps. Families of avocado, mango, and jackfruit have been produced that should allow the mapping of the genes involved with disease resistance, fruit quality, and yield. A candidate gene approach is also being used to find genes involved with disease resistance and for control of flowering (AyalaSilva et al., 2004; Schnell et al., 2001, 2003).

\section{Brownwood, Texas, established 1984}

The Brownwood Repository is located at $31.71^{\circ} \mathrm{N}$ latitude and has been the home of the USDA ARS Pecan Research program since 1933, when Louis Romberg began collecting pecan cultivars for use in breeding. On the recommendation of an active Crop Germplasm Committee, Romberg's grafted cultivar collections have been augmented by collections from native populations of pecan from throughout the range of the species (provenance collections) (Grauke et al., 1989), and by collections of other hickory (Carya) species, to provide the broadest base of genetically compatible germplasm. The 22 ha of Repository collections in Brownwood were supplemented in 1987 by addition of 21 ha at a worksite in Burleson County, Texas $\left(30.52^{\circ} \mathrm{N}\right.$ latitude). There are over 400 pecan cultivars in the collection represented by grafted trees at each worksite. Provenance collections are maintained as self-rooted trees, primarily at the Burleson County worksite. Over 300 provenance accessions are represented by up to 8 seedling trees each. Small collections of other hickory species from the United States, Mexico, and Asia (Grauke et al., 1991) are also maintained, with some accessions being represented only by herbarium or nut vouchers. Accessions are characterized for nut quality, phenology of growth and flowering, and for traits such as leaf and tree form. Research is focused on the refinement of descriptors for characterizing genetic diversity in Carya and the development of molecular genetic methods for fingerprinting accessions and characterizing populations (Grauke et al., 2003). A longterm goal of this Repository is the designation of appropriate and useful in situ reserves to more adequately represent this important native North American genus.

\section{Geneva, N.Y., established 1984}

The National Clonal Germplasm Repository for apple, grape, and tart cherry was established in 1984 on the campus of Cornell University in Geneva at $42.88^{\circ} \mathrm{N}$ latitude. In 1986, the Repository merged with the Northeast Regional Plant Introduction Station (NERPIS) and has been known since then as the Plant Genetic Resources Unit (PGRU). Currently, around 20,000 accessions are held, representing nearly 200 species and encompassing both seed-propagated and vegetatively propagated germplasm. The Malus (apple), Prunus cerasus (tart cherry), and Vitis (grape) collection comprises 5300 accessions. The PGRU also maintains a number of seedpropagated crops, including onion, tomato, and vegetable brassicas. Research activities focus on problems related to germplasm acquisition, collection management, and germplasm utilization, including application of whole plant phenotyping, cellular, and molecular markers to assess diversity of germplasm collections; development of improved apple rootstocks; and in vitro and cryopreservation of clonal and seed propagules.

The Malus collection includes 4000 accessions with 2500 of these maintained as trees grafted to EMLA 7 semidwarfing rootstock. Nearly all accessions are backed up in cryogenic storage at the National Center for Genetic Resource Preservation, Fort Collins, Colo. (NCGRP) as dormant buds; therefore, only one tree of each accession is maintained in the field. This provides a major cost savings by reducing acreage nearly $50 \%$. The other 1500 accessions are seed lots or seedling populations from wild collections
(Forsline et al., 2004). Seed collections are stored at $-20^{\circ} \mathrm{C}$ with equal amounts at PGRU and NCGRP. In addition, over 5000 seedlings are grown out and characterized at PGRU with some of these to be selected and maintained as clones. Others are used to produce seed backups (Volk et al., 2005).

The tart cherry collection includes approximately 100 accessions and represents the tetraploid cherries of Prunus cerasus and Prunus fruticosa. These are maintained as duplicate trees on MXM 2 rootstock. Over $50 \%$ are also backed up at NCGRP as dormant buds in cryogenic storage.

The grape collection consists of 1200 accessions, most of which are duplicated in the field as own-rooted plants. These accessions represent mostly North American native species and hybrids that are cold hardy and supplement the 2800 cold-tender Vitis accessions maintained in Davis, Calif. There is no cryogenic storage system for grapes, but maintaining them as own-rooted vines allows for reestablishment in the case of severe winter cold damage.

\section{Hilo, Hawaii, established 1986}

The National Clonal Germplasm Repository for Tropical Fruit and Nut Crops was initiated in 1986 as a joint cooperative project between the NPGS and the University of Hawaii at Manoa, College of Tropical Agriculture and Human Resources. The Repository is located at $19.57^{\circ} \mathrm{N}$ latitude. The unit became one of the 4 research units at the U.S. Pacific Basin Agricultural Research Center (PBARC) in 1999 and was renamed the Tropical Plant Genetic Resource Management Unit. Collections include approximately 1000 accessions maintained as living plants on 13 ha of field plantings at 3 locations with selected germplasm grown in tissue culture and in greenhouses. The unit is responsible for $14 \mathrm{important}$ tropical fruit and nut collections, including Ananas, Artocarpus, Averrhoa, Bactris, Camellia, Canarium, Carica, Dimocarpus, Litchi, Macadamia, Malpighia, Nephelium, Passiflora, and Psidium (Table 2). Research at Hilo focuses on germplasm maintenance, verification, and storage. Examples of research include in vitro storage, molecular fingerprinting, flower induction mechanism, fungal and bacterial diseases of tropical crops, and new crop evaluations (Keith et al., 2006; Matsumoto Brower 2006; Steiger et al., 2003).

\section{Riverside, Calif., established 1987}

The goal of the Riverside Repository is to provide the genetic diversity necessary to improve the productivity of citrus, date palms, and related taxa and to reduce genetic vulnerability of these crops for the future. This genebank is located at the University of California Riverside at $33.97^{\circ} \mathrm{N}$ latitude. Primary objectives are to collect, maintain, evaluate, preserve, and distribute pathogen-tested clonal germplasm of Citrus, 32 related Aurantioideae genera, and date palms and related Phoenix species. The secondary objectives are to conduct and encourage research on improved methods of maintenance, evaluation, preservation, and distribution. 
The Riverside Repository is somewhat unique among the clonal repositories in that it is truly a cooperative program with the University of California (UC), Riverside. The largest number of Citrus genotypes is maintained in a university field collection that is shared between ARS and UC. However, as a result of the unknown pathogen status of plants in the field, ARS maintains an additional protected collection of pathogen-tested trees in screenhouses. Screenhouse trees are the primary source for clonal distributions. In addition, the Repository is accredited by USDA-APHIS and the California Department of Food \& Agriculture for receiving foreign citrus introductions, which are used by both ARS and UC. Date palms are maintained by ARS at a UC facility in Thermal, Calif. Several satellite plantings of cold-sensitive genotypes are also maintained at other UC field stations. Research supporting the objectives of the Repository has focused on phytopathologic issues, including development of improved pathogen assays, investigation of abnormalities in field trees, and cooperative work with various entities toward establishing certification programs (Fang et al.,1997; Krueger \& Roose, 2003). Research on molecular characterization has permitted the designation of a "core" collection.

\section{Documentation of Collections-GRIN}

The Germplasm Resources Information Network or GRIN is the national public database that provides both genebank personnel and germplasm users access to passport, characterization, evaluation, inventory, and distribution data from the national germplasm collections. In addition to plant germplasm, GRIN also supports the National Animal Germplasm System, the National Microbial Germplasm Program, and the $\mathrm{Na}-$ tional Invertebrate Germplasm Program (NPGS, 2005b). Each repository is responsible for entering and maintaining data for collections at their site. Several database query options are available to the public at http:// www.ars-grin.gov/npgs/searchgrin.html.

\section{Maintenance and Backup Strategies}

Repositories must find a balance between maximizing diversity and minimizing the risk of loss. Some crops like apples, pears, pecans, and walnuts are economically maintained in long-lived orchard collections. Crops such as citrus, stone fruits, or strawberries are prone to insect-borne viruses and therefore must be protected in screenhouses to prevent plants from becoming infected. Maintaining multiple plants of each accession as in-house backup increases the security of the collection but reduces the space available for additional accessions. This is particularly true for potted plants maintained in screenhouses or greenhouses. Some repositories are using in vitro culture as a medium-term backup strategy for growing plants (Corvallis, Hilo, Mayaguez), and others are using cryogenic storage of either apical meristems or dormant buds for longterm backup (Corvallis, Geneva). However, for many tropical and subtropical crops, development of cryogenic or in vitro storage protocols is difficult and has not yet been implemented.

\section{Distribution Policies and Procedures}

Distribution of clonal germplasm is more complicated than distribution of seeds. Clonal repositories do not generally distribute finished rooted plants, but rather distribute scions or cuttings that must be propaguled by the recipient. Shipping of requested accessions is therefore dependent on the season when appropriate propagables are available. This might be early summer for strawberry runners or blueberry softwood cuttings or midwinter for grape cuttings or fruit tree scions. Propagation material of subtropical and tropical species is often available throughout the year. Germplasm is freely available from all NPGS Repositories in small quantities for research purposes. The National Plant Germplasm System distributes germplasm to foreign requesters in compliance with federal quarantine regulations and restrictions of the United States and the recipient country.

\section{Pathogen Testing}

Clonal repositories seek to distribute germplasm without disseminating germplasm-borne pathogens, including viruses, viroids, and phytoplasmas. Although not certified to be free of all known pathogens, much of the clonal germplasm in NPGS has been tested for the presence of common or important viruses and virus-like pathogens. Various testing methods are used depending on information available for each pathogen. Some pathogens can only be detected by inoculating indicator plants and observing symptoms, whereas other pathogens can be detected by modern laboratory methods (Jelkman, 2004; Martin, 2004; Postman et al., 2005; Schnell et al., 1997). Pathogen test results are often required before a phytosanitary certificate can be obtained for safe international germplasm exchange.

\section{Characterization}

Witt (1985), in his "BriefBook" on genetic diversity, quoted from a plant breeding report that compared germplasm collections with "pharmacies filled with miracle drugs without labels." We need to uncover the genes lurking in our germplasm that will allow us to develop cultivars able to overcome emerging diseases, adapt to changing climates, improve flavor, enhance nutritional value, and expand production into new environments. We must not only preserve our vanishing agricultural heritage, but also discover new sources of essential human nutrients, satisfy consumer desires for novel fruits and nuts, and implement reli- able methods to identify and "fingerprint" genotypes. Identification and elimination of duplicate genotypes will allow us to make more efficient use of resources. DNA techniques have become useful tools for both identifying clones and for locating the genes associated with useful traits. Our germplasm is only as useful as the information that accompanies it. GRIN provides a place to store geographic locality coordinates that allow plant origin maps to be generated and that will associate accessions with climate and environment data. Each Repository, in consultation with a team of crop specialists, has developed a list of "descriptors" or key traits that are of interest to plant breeders. Germplasm users can query GRIN for plants with traits that meet their specialized needs whether as parents for breeding or representatives of a unique geographic area.

\section{Technical Advisory and Crop Germplasm Committees}

Brooks and Barton (1977) in their original proposal for national fruit and nut repositories proposed Technical Advisory Committees to guide the development and operation of each genebank and Crop Advisory Committees, later renamed "Crop Germplasm Committees" or CGCs to guide curators in the management of specific collections. CGCs are national working groups made up of specialists representing various disciplines and include federal, state, and private industry members. These committees help curators identify and fill gaps in U.S. collections, prioritize traits for evaluation, appraise research proposals, and help ensure the accuracy of data entered to the GRIN. CGC members also assist in the designation of core subsets (NPGS, 2005c). Fruit and nut crops represented by CGCs are:
o Carya
o Citrus and Phoenix
o Juglans
o Malus
o Prunus
o Pyrus
o Vitis
o Small fruits (berries)
o Tropical fruits and nuts

\section{Future Challenges}

Twenty-five years after their inception, the NPGS Clonal Germplasm Repositories have established valuable national collections representing world diversity of not only commercially important fruit and nut cultivars, but also their wild relatives, which may have genetic traits of unanticipated importance. Cohen et al. (1991) defined 4 eras in ex situ crop germplasm conservation:

1. A period of exploration and acquisition from the early 1800 s to approximately 1950 ;

2. A period of establishing conservation facilities from the 1950 s to the 1980 s;

3. A period focused on regeneration and research from 1980 to the second decade of the 21 st century; and 
4. A future era of enhanced utilization.

Workers at NPGS clonal genebanks had a late start on this roadmap, but have now entered the era where regeneration and evaluation of collections are priorities. Crop germplasm collections were originally conceived as a "hedge against starvation" (Loewer, 1991), but as collections become more complete, they become valuable for more than just crop improvement (Greene and Morris, 2001). Some species in NPGS collections are rare or endangered in the wild, making these genebanks conservators of plants that may become extinct in nature. Today's plant explorers build on knowledge of plant distributions that were often established by NPGS collectors. Secondary and tertiary gene pools captured in our genebanks are being used for basic research on evolution and genetic relationships. Patent and trademark attorneys consult the GRIN database and NPGS curators as important references on cultivar names or traits. Artists and photographers visit our collections to document accessions in other ways. Future challenges include identifying gaps in collections and acquiring plants to fill those gaps. Recent international agreements such as the Convention on Biological Diversity (CBD, 2006) and the International Treaty on Plant Genetic Resources for Food and Agriculture (FAO, 2006) have redefined the protocols for exchange of plant genetic resources between countries. National quarantine regulations that prevent the movement of insect and disease pests also impact international germplasm exchange. Genebank personnel will be challenged to maintain expanding collections with declining resources and transition from the acquisition phase to the evaluation phase as collections mature. Eliminating unintended redundancy, filling genetic gaps, and expanding phenotype and genotype data in GRIN will continue to enhance the value of the NPGS fruit and nut collections. Cohen's era of enhanced utilization (Cohen et al., 1991), when mature genebanks expand their partnerships with breeders, researchers, and stakeholders, has arrived for the NPGS clonal repositories.

\section{Literature Cited}

Aradhya, K.M., G.S. Dangl, B.H. Prins, J.M. Boursiquot, A.M. Walker, C.P. Meredith, and C.J. Simon. 2003. Genetic structure and differentiation in cultivated grapes, Vitis vinifera. L. Genet. Res. 81:179-192.

Aradhya, K.M., C. Weeks, and C.J. Simon. 2004 Molecular characterization of diversity and relationships within and among seven cultivated species of Prunus. Sci. Hortic. (Amsterdam) 103:131-144.

Aradhya, K.M., D. Potter, F. Gao, and C.J. Simon, 2005. Cladistic biogeography of Juglans (Juglandaceae) based on chloroplast DNA intergenic spacer sequences. pp. 143-170. In: Motley, T.J., Zerega, and H. Cross (eds). Darwin's Harvest-New Approaches to the Origin, Evolution, and Conservation of Crops. Columbia University Press, New York.

Ayala-Silva, T., R.J. Schnell, A.M. Meerow, R Goenaga, and F. Zee. 2004. Current status of the subtropical and tropical germplasm repositories of the National Plant Germplasm System. Proc. Fla. State Hort. Soc. 117:182-187.
Bassil, N.V., R. Botta, and S.A. Mehlenbacher. 2005. Microsatellite markers in hazelnut: isolation, characterization and cross-species amplification. J. Am. Soc. Hortic. Sci. 130:543-549.

Brooks, H.J. and D.W. Barton. 1977. A plan for national fruit and nut germplasm repositories. HortScience 12:298-300.

CAST, 1985. Plant germplasm preservation and utilization in U.S. agriculture. Council for Agricultural Science and Technology, Ames, Iowa. Report No. 106., 35 pp.

CBD. 2006. Convention on Biological Diversity. United Nations Environmental Programme. Quebec, Canada. Available at: http://www.biodiv.org/default.shtml. Accessed April 6, 2006.

Cohen, J.I., J.T. Williams, D.L. Plucknett, and H. Shands. 1991. Ex situ conservation of plant genetic resources: global development and environmental concerns. Science 253:866-872.

Fang, D.Q., M.L. Roose, R.R. Krueger, and C.T. Federici. 1997. Fingerprinting trifoliate orange germplasm accessions with isozymes, RFLPs, and inter-simple sequence repeat markers. Theor. Appl. Genet. 95:211-219.

FAO. 2006. International Treaty on Plant Genetic Resources for Food and Agriculture. Commission on Plant Genetic Resources for Food and Agriculture. UN/FAO Rome. Available at: http://www.fao.org/AG/cgrfa/itpgr.htm. Accessed April 62006.

Forsline, P.L.H.S. Aldwinckle, E.E. Dickson, J.J. Luby and S.C. Hokanson. 2004. Collection, Maintenance, Characterization and Utilization of Wild Apples of Central Asia, pp. 1-61. In: J. Janick, P. Forsline, E. Dickson, R. Way, and M. Thompson (eds.). Horticultural Reviews, vol. 29 Wild Apple and Fruit Trees of Central Asia. Wiley, New York.

Grauke, L.J., M.J. Iqbal, A.S. Reddy, and T.E. Thompson. 2003. Development of microsatellite DNA markers in pecan. J. Am. Soc. Hortic. Sci. 128:374-380.

Grauke, L.J., J.A. Payne, and B.W. Wood. 1989. North American pecans: a provenance study. Annu. Rpt. North. Nut Growers Assn. 80:124-131.

Grauke, L.J., B.W. Wood, and J.A. Payne. 1991 Genetic resources of Carya in Vietnam and China. Annu. Rpt. N. Nut Growers Assn. 82:80-87.

Greene, S.L. and J.B. Morris. 2001. Crop Science 41:886-892.

Gupta, S. and B.M. Reed. 2006. Cryopreservation of shoot tips of blackberry and raspberry by encapsulation-dehydration and vitrification. CryoLetters 27(1):29-42.

Jahn, O.L. and M.N. Westwood. 1982. Maintenance of clonal plant germplasm. HortScience 17:122.

Jelkman, W. 2004. Detection of virus and viruslike diseases of fruit trees. Acta Hortic. 657: 575-596.

Keith, L.M., M. Velasquez, and F.T. Zee. 2006. Identification and characterization of Pestalotiopsis Spp. causing scab disease of guava, Psidium Guajava L. in Hawaii. Plant Dis. 90:16-23.

Krueger, R. and M.L. Roose. 2003. Use of molecular markers in the management of citrus germplasm resources. J. Am. Soc. Hortic. Sci. 128:827-837.

Lewers, K.S., N.V. Bassil, S.M. Styan, and S.C. Hokanson. 2005. Strawberry GenBank-derived and genomic simple sequence repeat (SSR) markers and their utility with strawberry, blackberry, and red and black raspberry. J. Am. Soc. Hortic. Sci. 130:102-115.

Loewer, P. 1991. A hedge against starvation. American Horticulturist June: 38-44.
Matsumoto Brower, T.K. 2006. Genes uniquely expressed in vegetative and potassium chlorate induced floral buds of Dimocarpus Longan. Plant Sci. 170:500-516.

Martin, R.R. 2004. Recommended procedures for detection of viruses of small fruit crops. Acta Hortic. 656:199-207.

Mehlenbacher, S.A., R.N. Brown, E.R. Nouhra, and N.V. Bassil. 2005. A genetic linkage map for hazelnut (Corylus avellana L.) based on RAPD and SSR markers. Genome 49:122-133.

NPGS. 2005a. The National Plant Germplasm System. Available at: http://www.ars-grin.gov/ npgs/. Accessed November 22, 2005.

NPGS. 2005b. The Germplasm Resources Information Network. Available at: http://www.ars grin.gov/aboutgrin.html. Accessed November 22, 2005.

NPGS. 2005c. Crop Germplasm Committees. Available at: http://www.ars-grin.gov/npgs/ aboutcgc.html. Accessed November 22, 2005.

NPGS. 2006. Summary Statistics for GRIN. Available at: http://www.ars-grin.gov/npgs/stats/. Accessed January 12:2006.

Postman, J.D., J.S. DeNoma, and B.M. Reed. 2005. Detection and elimination of viruses in USDA hop (Humulus lupulus) germplasm collection. Acta Hortic. 668:143-148.

Reed, B.M. 2001. Implementing cryogenic storage of clonally propagated plants. Cryo Letters 22:97-104.

Reed, B.M., L. Schumacher, D. Dumet, and E.E. Benson. 2006. Evaluation of a modified encapsulation-dehydration procedure incorporating high sucrose pretreatments for the cryopreservation of Ribes germplasm. In Vitro Cell. Dev. Biol. Plant 41:431-436.

Schnell, R.J., D.M. Kuhn, C.M. Ronning, and D. Harkins. 1997. Application of RT-PCR for indexing avocado sunblotch viroid. Plant Dis. 81:1023-1026.

Schnell, R.J., C.T. Olano, R.J. Cambell, and J.S. Brown. 2001. AFLP analysis of genetic diversity within a jackfruit germplasm collection. Scientia Hort. 1661:1-14.

Schnell, R.J., J.S. Brown, C.T. Olano, E.J. Power, C.A. Krol, D.N. Kuhn, and J.C. Motamayor. 2003. Evaluation of avocado germplasm using microsatellite markers. J. Am. Soc. Hortic. Sci. 128:881-889.

Steiger, D., P. Moore, F.T. Zee, Z. Liu, and R. Ming. 2003. Genetic relationships of macadamia cultivars and species revealed by Aflp markers. Euphytica 132:269-277.

Volk, G.M., A.A. Reilley, A.D. Henk, C.M. Richards, P.L. Forsline, and H.S. Aldwinckle. 2005. Ex situ conservation of vegetatively propagated species: development of a seedbased core collection of Malus sieversii. J. Am. Soc. Hortic. Sci. 130:203-210.

Westwood, M.N. 1982. Pear germplasm of the new National Clonal Repository: its evaluation and uses. Acta Hortic. 124:57-66.

Westwood, M.N. 1986. U.S. establishes national clonal repository system for fruit and nut crops. Diversity 9:19-21.

Westwood, M.N. 1989. Maintenance and Storage: Clonal Germplasm. Plant Breeding Reviews, vol. 7. Timber Press, Portland, OR, pp. 111-128.

White, G.A., H.L. Shands, and G.R. Lovell. 1989. History and Operations of the National Plant Germplasm System. Plant Breeding Reviews, vol. 7. Timber Press, Portland, OR, pp. 5-56.

Witt, S.C. 1985. Biotechnology and Genetic Diversity. California Agricultural Lands Project, San Francisco, 145 pp. 